\title{
MicroRNAs and the cancer phenotype: profiling, signatures and clinical implications
}

\author{
Carlos Stahlhut and Frank J Slack
}

\begin{abstract}
MicroRNAs (miRNAs) have emerged as key genetic regulators of a wide variety of biological processes, including growth, proliferation, and survival. Recent advances have led to the recognition that miRNAs can act as potent oncogenes and tumor suppressors, playing crucial roles in the initiation, maintenance, and progression of the oncogenic state in a variety of cancers. Determining how miRNA expression and function is altered in cancer is an important goal, and a necessary prerequisite to the development and adoption of miRNA-based therapeutics in the clinic. Highly promising clinical applications of miRNAs are the use of miRNA signatures as biomarkers for cancer (for example, for early detection or diagnosis), and therapeutic supplementation or inhibition of specific miRNAs to alter the cancer phenotype. In this review, we discuss the main methods used for miRNA profiling, and examine key miRNAs that are commonly altered in a variety of tumors. Current studies underscore the functional versatility and potency of miRNAs in various aspects of the cancer phenotype, pointing to their potential clinical applications. Consequently, we discuss the application of miRNAs as biomarkers, clinical agents, and therapeutic targets, highlighting both the enormous potential and major challenges in this field.
\end{abstract}

\section{MicroRNAs: potent and versatile gene regulators in cancer}

All types of cancers are characterized by the disruption of cellular homeostasis pathways, resulting in enhanced cell growth and proliferation, and in decreased susceptibility to the programs causing cell death. Studies have revealed that miRNAs can target many of the programs

\footnotetext{
* Correspondence: frank.slack@yale.edu

Department of Molecular, Cellular and Developmental Biology, Yale University, PO Box 208103, New Haven, CT 06520, USA
}

that regulate these essential cellular functions, suggesting that miRNAs can play key roles in the initiation, maintenance, and progression of the oncogenic state $[1,2]$. Indeed, expression profiling has revealed that tumors of different types and origins have altered miRNA profiles, and that a large proportion of known miRNA loci are located in areas of the genome associated with cancer [3]. Furthermore, numerous studies have revealed a strong correlation between altered miRNA expression and oncogenesis, underscoring the importance of miRNAs in cancer $[1,2]$. These findings suggest that miRNA signatures might serve as valuable biomarkers, aiding in the detection of cancer and its correct classification.

miRNAs are a class of non-coding RNAs that have potent and versatile roles in development and disease, affecting key cellular processes such as proliferation, apoptosis, and differentiation $[4,5]$. These small ( 18-25 nucleotides) RNAs can bind target mRNAs in a sequence-specific fashion to induce their post-transcriptional downregulation. This binding is dependent on the 'seed sequence,' a 6-8-nucleotide sequence at the $5^{\prime}$ end of each miRNA that is complementary to sites found in the $3^{\prime}$ untranslated region (UTR) of target mRNAs (target sites). The mechanisms governing the interaction of miRNAs with their target genes remain somewhat unclear, but it is thought that individual miRNAs can target multiple genes for regulation, and that these targets are extremely diverse in cellular function, suggesting that miRNAs play important roles in a wide variety of cellular processes [6-8].

Here, we first discuss the major techniques currently used to profile miRNAs from a variety of biological sources, including clinical samples. We then discuss the expression signatures of key miRNAs in several cancers, highlighting the molecular pathways through which they may be acting to control cell proliferation, survival, and invasion. Finally, we discuss miRNAs in cancer from a clinical perspective. We address the use of miRNAs as biomarkers for disease, as therapeutic agents, and as targets for other agents, illustrating the importance and versatility of miRNAs in this disease. 


\section{MicroRNA profiling methods}

miRNA expression profiles can provide valuable information about tumor progression, angiogenic potential, and metastatic risk [2,9], making miRNA profiling an area of great clinical interest. Several techniques for the detection of miRNA levels have been developed to profile miRNAs from a variety of biological materials, including patient samples. These include approaches based on quantitative PCR (qPCR), microarrays and next-generation sequencing (Table 1).

qPCR is a popular technology for profiling miRNA levels, offering high sensitivity, a large dynamic range, and reproducibility. A variety of commercially available platforms make the quantitation of specific miRNAs a technique that is accessible to virtually any laboratory with PCR capabilities. Like other PCR-based techniques, qPCR profiling requires a small amount of input material; moreover, the technique is compatible with a wide variety of sample sources, including patient samples and formalin-fixed, paraffin embedded tissues [9]. This is an important advantage in the clinical setting, where the amounts of patient sample are often very limited.

Despite its many advantages, qPCR-based profiling has important limitations. Because available qPCR assays are generally designed to profile single miRNAs, this technique is generally low-throughput, and can be limited by scalability if a large number of miRNAs need to be examined. However, the introduction of microfluidic array platforms has made it possible to assess the levels of thousands of miRNAs in parallel from small amounts of sample [10,11], offering a high-throughput application of qPCR profiling. Several technical challenges also exist in qPCR profiling. The synthesis of cDNA from purified RNA is subject to errors and variation resulting from secondary structure, differences in priming efficiency, and biases caused by the reverse transcriptase used [12,13]. In addition, large-scale comparison of multiple miRNAs can be challenging because of differences in the amplification parameters among miRNAs, particularly concerning the melting temperature for each primer set. The use of modified primers, including stem-loop primers and primers incorporating lockednucleic acids can help to alleviate some of these issues.

While qPCR is best suited to the detection of specific miRNAs of interest, other detection techniques have been developed to assess global miRNA levels. Oligonucleotide miRNA microarray analysis was originally the most popular high-throughput technique, allowing for the analysis of hundreds of miRNAs in a large number of samples $[14,15]$. The approach usually involves RNA or miRNA isolation, labeling with a fluorophore, and then hybridization to microarrays containing collections of probes with sequence complementarity to miRNAs of interest. Despite its throughput and global profiling ability, microarray analysis was limited by its requirement for high amounts of starting material to produce robust results. In addition, the size of the oligonucleotides used for detection, and therefore the specificity of detection, was limited by the short size of miRNAs. As a consequence, microarrays often detected both the mature and precursor forms of miRNAs, boosting sensitivity but confounding the results if precise measurements of mature miRNA levels are important. In addition, technical biases can be introduced at the RNA-labeling step, leading to the development of label-free systems in which the fluorophore selectively binds miRNA-probe duplexes [16]. Like qPCR, microarrays can be affected by differences in probe-miRNA affinity, leading to the introduction of biases and variability from assay to assay.

The growth of new next-generation sequencing platforms and associated bioinformatics tools has made it

Table 1 Major platforms for microRNA profiling

\begin{tabular}{|c|c|c|c|c|c|}
\hline Method & Execution time & Sample input & Cost & Advantages & Disadvantages \\
\hline qPCR & $<6$ hours & $10-500 \mathrm{ng}$ & $<\$ 300$ & $\begin{array}{l}\text { High sensitivity, large dynamic } \\
\text { range ( } 6 \text { orders of magnitude), } \\
\text { reproducibility, accessibility, } \\
\text { compatible with several sources } \\
\text { of biological material }\end{array}$ & $\begin{array}{l}\text { Low throughput, unable to } \\
\text { detect novel or modified } \\
\text { miRNAs, variability across platforms }\end{array}$ \\
\hline $\begin{array}{l}\text { Microfluidic qPCR } \\
\text { platforms }\end{array}$ & $<6$ hours & $10-500 \mathrm{ng}$ & $<\$ 300$ & $\begin{array}{l}\text { High throughput, high sensitivity, } \\
\text { large dynamic range ( } \sigma \text { orders of } \\
\text { magnitude), reproducibility, } \\
\text { compatible with several sources } \\
\text { of biological material }\end{array}$ & $\begin{array}{l}\text { Unable to detect novel or modified } \\
\text { miRNAs, variability across platforms }\end{array}$ \\
\hline Microarray & 48 hours & $100 \mathrm{ng}-1 \mu \mathrm{g}$ & $\sim \$ 300$ & $\begin{array}{l}\text { High throughput, well optimized, } \\
\text { well established analysis methods }\end{array}$ & $\begin{array}{l}\text { Generally cannot distinguish mature } \\
\text { from pre-miRNAs, might require a } \\
\text { non-specific amplification step }\end{array}$ \\
\hline $\begin{array}{l}\text { Next generation } \\
\text { sequencing }\end{array}$ & 2 weeks & $500 \mathrm{ng}-5 \mu \mathrm{g}$ & $>\$ 1000$ & $\begin{array}{l}\text { High throughput, useful for miRNA } \\
\text { discovery and modified miRNA } \\
\text { detection, high sensitivity, } \\
\text { large dynamic range } \\
\text { ( } \sim 5 \text { orders of magnitude) }\end{array}$ & $\begin{array}{l}\text { Large investment and bioinformatics } \\
\text { expertise required, slow turnover, } \\
\text { may suffer from non-linearity in the } \\
\text { amplification step }\end{array}$ \\
\hline
\end{tabular}


possible to overcome several of the limitations of microarray-based global analysis. This technique allows users to profile all known miRNAs from a single sample, while also being able to identify novel miRNAs and modifications to known miRNAs. In addition, sequencing provides a large dynamic range, particularly when ample input material is available [9]. These characteristics give next-generation sequencing unparalleled power for global analysis of miRNA expression, particularly when the detection of miRNA variants or novel miRNAs is desirable.

Despite these valuable advantages, the broad adoption of next-generation sequencing is limited by challenges in library preparation, data analysis and cost. This technique relies on the production of cDNA libraries, which are amplified by PCR. This opens the possibility of testing global miRNA levels in samples with little starting material, but it suffers from nonlinearity in the measurement process [9], with miRNAs expressed at very high or very low levels being the most affected by this issue. Likewise, technical issues, particularly concerning variability in adapter ligation and differences in enzymatic efficiency, can affect this technique. Finally, this approach is more susceptible to noise than qPCR or microarray analysis, because it is able to detect RNA degradation products. Another challenge for the broad adoption of sequencing is the complexity of data analysis, requiring expertise in bioinformatics and statistics. Publicly available software packages have made this process more accessible, but it still demands much greater expertise and analysis time than qPCR or microarrays.

Together, these miRNA profiling platforms make it possible to evaluate miRNA expression from a wide variety of biological samples $[17,18]$. The choice of platform depends on the goals of the investigator, as well as convenience, available expertise, and cost. Using these approaches, a series of investigations have revealed miRNA signatures of various cancers, tissues, and responses to therapy.

\section{MicroRNA signatures of cancer}

The development of effective miRNA-profiling methods has led to the recognition that miRNAs can act as potent oncogenes and tumor suppressors, playing key roles in the initiation and progression of the oncogenic state in a wide variety of cancers. miRNAs that promote cellular processes linked to oncogenesis and tumor progression, such as uncontrolled proliferation, increased invasiveness, and resistance to apoptosis, are called 'oncomiRs', and are often upregulated in cancer. By contrast, miRNAs that counteract these oncogenic characteristics are called 'tumor-suppressor miRNAs', and are often downregulated in cancer. Certain miRNA can have either oncogenic or tumor-suppressor roles depending on the cellular context. In this section, we discuss
miRNAs that have been identified to play important roles in oncogenesis, and the molecular mechanisms through which they might be acting. Table 2 summarizes commonly dysregulated miRNAs in cancer and their key targets.

\section{Oncogenic microRNAs}

Here, we first discuss several examples of miRNAs that have been found to have largely oncogenic roles in cancer.

\section{miR-17 92 cluster}

The polycistronic miR-17 $\sim 92$ cluster is processed to produce six mature miRNAs: miR-17, miR-18a, miR19a, miR-20a, miR-19b-1, and miR-92a-1 [19,20]. This cluster has been found to possess oncogenic behavior in a wide variety of cancers, including cancers of the lung, breast, pancreas and colon as well as B-cell lymphoma, retinoblastoma, and glioblastoma [21-25]. miRNAprofiling studies have revealed that the miR-17 $\sim 92$ cluster is overexpressed in lung cancer cells $[23,26]$. Notably, the genomic locus encoding the miR-17 92 cluster, 13q31.3, is amplified in several types of lymphoma and in a variety of solid tumors [27]. Moreover, both E2F family members and MYC (transcription factors that are known to be dysregulated in several cancers and that lead to increased proliferation) are able to activate the expression of this miRNA cluster, providing a mechanism for its elevated levels in cancer [28,29].

The miR-17 92 cluster can target several key genes, thereby affecting multiple aspects of cancer initiation and progression. Among these, HIF-1 $\alpha$ has been identified as a direct target of miR-17 $\sim 92$, affecting the response of cancer cells to hypoxia [30]. Other key targets of miR-17 92 include genes that are involved in cell proliferation and signal transduction, such as PTEN, $E 2 F 1-3, T N F-\alpha$, and $R A B 14$, as well as genes that are associated with cell survival mechanisms, such as BIM and TGFBR2 [26,28,31-33]. Furthermore, this miRNA cluster is able to affect the tumor microenvironment by targeting TSP1 and CTGF, which play important roles in tumor angiogenesis.

Two miRNAs in the miR-17 92 cluster, miR-19a and miR-19b, play key roles in the induction of B-cell lymphoma. These miRNAs share extensive sequence identity, including in their seed sequence, and are often referred to collectively as miR-19. Olive et al. [34] and $\mathrm{Mu}$ et al. [35] analyzed the individual oncogenic potential of the six miRNAs encoded by the miR-17 $~ 92$ cluster, finding that miR-19 is essential to the tumorigenic activity of this cluster. Additionally, these studies showed that miR19 can target the tumor suppressor PTEN, while also being able to activate the Akt-mTOR pathway, suggesting that miR-19 may promote tumorigenesis by promoting 
Table 2 MicroRNAs commonly affected in cancer and their targets

\begin{tabular}{|c|c|c|c|}
\hline MicroRNA & $\begin{array}{l}\text { Oncogene or } \\
\text { tumor suppressor }\end{array}$ & Cancer types & $\begin{array}{l}\text { Key targets (and their } \\
\text { functions) }\end{array}$ \\
\hline \multirow[t]{4}{*}{ miR-17 92 cluster [19-36] } & \multirow[t]{4}{*}{$\mathrm{OG} / \mathrm{TS}$} & \multirow{4}{*}{$\begin{array}{l}\text { Lung, breast, pancreas, colon, } \mathrm{BCL} \text {, } \\
\text { retinoblastoma, glioblastoma }\end{array}$} & HIF-1a (hypoxia response) \\
\hline & & & $\begin{array}{l}\text { PTEN, E2F1-3, TNF-a, RAB14 } \\
\text { (cell proliferation) }\end{array}$ \\
\hline & & & BIM, TGFBR2 (cell survival) \\
\hline & & & TSP1, CTGF (tumor angiogenesis) \\
\hline \multirow[t]{3}{*}{ miR-21 [37-53] } & \multirow[t]{3}{*}{ OG } & \multirow[t]{3}{*}{ Lung, breast, lymphoma, glioblastoma } & PTEN, SPRY1, SPRY2, (cell proliferation) \\
\hline & & & PDCD4, APAF1 (cell survival) \\
\hline & & & TPM-1, TPM-3, RECK (metastasis) \\
\hline \multirow[t]{2}{*}{ miR-155 [26,42,54-61] } & \multirow[t]{2}{*}{ OG } & \multirow[t]{2}{*}{ Lung, lymphoma, breast } & FOXO3A, SHIP1, SOCS1 (cell survival) \\
\hline & & & RhoA (metastasis) \\
\hline \multirow[t]{2}{*}{ miR-221 or miR-222 [45,62-67] } & \multirow[t]{2}{*}{ OG } & \multirow[t]{2}{*}{ Lung, glioblastoma } & KIT, p27, PUMA (cell survival) \\
\hline & & & PTEN (cell proliferation) \\
\hline \multirow[t]{2}{*}{ let-7 [68,69,78-83] } & \multirow[t]{2}{*}{ TS } & \multirow[t]{2}{*}{$\begin{array}{l}\text { Lung, lymphoma, gastric, prostate, } \\
\text { breast, ovarian }\end{array}$} & $\begin{array}{l}\text { KRAS, NRAS, CDC25A, c-MYC } \\
\text { (cell proliferation) }\end{array}$ \\
\hline & & & HMGA2 (metastasis) \\
\hline \multirow[t]{3}{*}{ miR-34 [84-88,91-93] } & \multirow[t]{3}{*}{ TS } & \multirow[t]{3}{*}{$\begin{array}{l}\text { Lung, lymphoma, pancreas, colon, } \\
\text { neuroblastoma, glioblastoma }\end{array}$} & $\begin{array}{l}\text { CDC25A, CDK4, CDK6, c-MYC } \\
\text { (cell proliferation) }\end{array}$ \\
\hline & & & MET (metastasis) \\
\hline & & & BCL2 (cell survival) \\
\hline \multirow[t]{2}{*}{ miR-15/16 [94-98] } & \multirow[t]{2}{*}{ TS } & \multirow[t]{2}{*}{ CLL, multiple myeloma, prostate, pancreas } & BCL2 (cell survival) \\
\hline & & & $\begin{array}{l}\text { CDC2, JUN, FGF-2, CCND-1 } \\
\text { (cell proliferation) }\end{array}$ \\
\hline miR-200 [99-102] & TS & Breast, renal, gastric, bladder & $\begin{array}{l}\text { ZEB1, ZEB2 (cell differentiation } \\
\text { and metastasis) }\end{array}$ \\
\hline miR-181 [103,104] & TS & Glioma, lymphoma & TCL1 (cell survival) \\
\hline \multirow[t]{2}{*}{ miR-29 [105-112] } & \multirow[t]{2}{*}{ TS } & \multirow[t]{2}{*}{ CLL, hepatocellular carcinoma, breast } & MCL1, TCL1 (cell survival) \\
\hline & & & DNMT1 (gene expression) \\
\hline
\end{tabular}

BCL, B-cell lymphoma; CLL, chronic lymphocytic leukemia; OG, oncogene; TS, tumor suppressor.

cell survival. Intriguingly, two other miRNAs within the miR-17 92 cluster, miR-17-5p and miR-20a, can regulate the transcription factor E2F1, which plays a key role in controlling cell proliferation by regulating genes involved in cell-cycle progression, DNA replication, cell division, and apoptosis [36]. E2F1 is part of a positivefeedback loop with MYC, suggesting a model in which MYC induces both E2F1 and miR-17 92. In turn, this miRNA cluster can repress E2F1 levels to curb the cell proliferative effects of MYC mediated by E2F1 [29]. In this context, miR-17-5p and miR-20a would act as tumor suppressors, highlighting the complexity and versatility of miRNA-mediated regulation in cancer.

\section{miR-21}

Several studies have found that the levels of miR-21 are elevated in different types of cancer, including lung, breast, lymphoma, and glioblastoma. Lung tumor profiling studies revealed that elevated miR-21 expression was most notable in patients with mutations in the epidermal growth factor receptor (EGFR) gene. Additionally, miR21 levels were correlated with phosphorylated EGFR (p-EGFR) levels, and miR-21 overexpression could be ablated by the use of EGFR tyrosine kinase inhibitors in cell culture. The discovery that blocking miR-21 with antisense oligonucleotides results in elevated apoptosis in a p-EGFR-dependent manner suggests that miR-21 acts as an anti-apoptotic factor, which is negatively regulated by EGFR signaling [37]. Further support for an anti-apoptotic role for miR-21 is provided by the identification of several potent pro-apoptotic targets, including Apaf1, Faslg, RhoB, and Pdcd4 [38].

In addition to its role in apoptosis, miR-21 appears to modulate cell growth and proliferation by targeting several key signaling axes, further suggesting an important role for this miRNA in tumorigenesis. miR-21 can target the potent tumor suppressor gene PTEN, as well as negative regulators of the RAS signaling axis including Spry1, Spry2, and Btg2, enhancing cell proliferation $[38,39]$. In addition, several key cell-cycle regulators are 
predicted to be miR-21 targets [40]. Notably, antisense oligonucleotides against miR-21 can inhibit cell growth in culture, highlighting the importance of this miRNA for the proliferation of cancer cells [41].

Microarray-based profiling of tumor samples from breast cancer patients found that miR-21 was consistently upregulated in several types of breast cancer, suggesting a role for this miRNA in mammary tumor initiation or progression [42]. Cell-culture-based studies further supported this notion, indicating that inhibition of miR-21 with antisense oligonucleotides in human breast cancer cells resulted in reduced cell proliferation in vitro and in tumor xenograft systems. This reduction was accompanied by elevated rates of apoptosis, which correlated with decreased expression of the key antiapoptotic factor BCL-2 [43].

miR-21 has been identified as being upregulated in glioblastomas, and miR-21 knockdown in glioblastoma cell lines results in caspase activation and elevated apoptotic rates, indicating a pro-survival function for miR-21 [44-48]. While the targets of miR-21 in glioblastoma have not been ascertained, it is likely that the tumor suppressors PTEN, TPM1, and PDCD4, which are targets in other types of tumor, might also play a role in promoting glioblastoma cell survival and proliferation [49-51]. In addition, miR-21 can target inhibitors of matrix metalloproteases such as RECK and TIMP3, contributing to the aggressive invasiveness that characterizes this disease $[46,52]$.

The oncogenic potential of miR-21 has also been observed in mouse models of lung cancer, where overexpression of this miRNA resulted in increased tumor proliferation, whereas miR-21 deletion reduced tumor incidence [38]. Similar observations were made using a mouse model of pre-B-cell lymphoma (BCL), which showed that miR-21 overexpression leads to pre-BCL, which is wholly dependent on the continued expression of miR-21 [53]. Together, these findings highlight the role of 'oncomiR addiction' in cancer, suggesting that the presence of specific or constant amounts of such oncogenic miRNAs is needed to maintain the tumor phenotype, and that the tumor cells fail to survive when the expression of these miRNAs ceases.

\section{$\operatorname{miR}-155$}

miR-155 plays an important role in the regulation of oncogenesis, and particularly in the response and adaptation to the tumor microenvironment. miR-155 is overexpressed in lung cancers [26,54], and high levels of miR-155 correlated with poor overall survival in squamous cell carcinoma and non-small-cell lung cancer (NSCLC) patients [54,55]. Similarly, miR-155 is upregulated in several types of lymphoma, and mice that overexpress miR-155 in B-cells develop BCL [56]. Notably, in mice with established BCL resulting from miR-155 overexpression, cessation of miR-155 expression results in rapid regression, indicating a role for this miRNA in the maintenance of the oncogenic state [57]. miR-155 was also identified in early breast tumor profiling studies as being consistently upregulated across a variety of breast cancer cell types. Expression of miR-155 in breast cancer cells results in enhanced proliferation and colony formation in culture and soft agar assays, as well as enhanced tumor formation in nude mouse models $[26,42]$.

While the mechanism governing miR-155 upregulation in cancer is not yet known, recent evidence suggests that the expression of this miRNA is induced in response to hypoxic conditions, and that this response results in the downregulation of key miR-155 targets such as FOXO3A [58]. This response is dependent on the hypoxic factor HIF-1- $\alpha$, suggesting that it may act as part of a broader system in the oncogenic response to hypoxia. Moreover, these findings suggest that miR-155 plays a key role in the adaptation response enacted by tumors in response to the microenvironment. Other key targets of this miRNA include SOCS1, an important modulator of cytokine signaling [59], and FOXO3, suggesting a broad role in the regulation of cell signaling [60]. In addition to its role in modulating cell survival and proliferation, miR-155 is involved in the regulation of metastasis. Specifically, miR155 can regulate the key cellular factor RhoA, thereby modulating the levels of epithelial cadherin (E-cadherin) to promote epithelial-to-mesenchymal transition (EMT; the cellular process through which epithelial cells lose their polarity and exhibit decreased cell-cell adhesion, resulting in increased invasive potential) and to induce cell migration in response to TGF- $\beta$ signaling [61].

miR-155 also plays an important role in cancer therapy by modulating the response to radiation treatment. Babar and colleagues [58] have recently shown that miR155 overexpression resulted in decreased radiationinduced cell death, whereas inhibition of miR-155 using antisense oligonucleotides resulted in increased radiosensitivity. Together, these results suggest that miR-155 may be contributing to poor patient prognosis by affecting not only the initiation and progression of cancer but also the response of tumor cells to radiation treatment and other environmental insults such as hypoxia.

\section{Cancer cell survival and metastasis: miR-221 and miR-222}

miR-221 and miR-222 are miRNAs that have potential roles in promoting the survival of cancer cells. These miRNAs are upregulated in NSCLC cells that are resistant to the pro-apoptotic factor Apo2L/TNF- $\alpha$-related apoptosis-inducing ligand [62]. The anti-apoptotic properties of miR-221 and miR-222 may result from their ability to target pro-apoptotic factors such as Kit, $p 27^{\text {Kip1 }}$, PTEN, and PUMA [62-64]. 
In addition to their anti-apoptotic properties, miR-221 and miR-222 can promote tumor metastasis by activating the AKT pathway and several key metalloproteases, thereby facilitating tumor extracellular matrix breakdown and tumor migration. Indeed, elevated levels of miR-221 and miR-222 are observed in aggressively invasive forms of lung cancer [62], suggesting that these miRNAs may play important roles in enhancing the metastatic potential of lung tumors.

miR-221 and miR-222 are also overexpressed in glioblastoma tumor samples and in glioblastoma cell lines $[45,65,66]$. In these cancers, the action of miR-221 appears to be centered on the repression of the cell-cycle regulator $\mathrm{p} 27^{\mathrm{Kip} 1}$, an important inhibitor of the cyclindependent protein kinases [67]. By targeting p27, miR221 and miR-222 can help to bypass cell-cycle controls to promote rapid cell proliferation and growth.

\section{Tumor suppressor microRNAs}

Here, we discuss several examples of miRNAs that have been found to have largely tumor suppressor roles in cancer.

\section{let-7}

The let-7 family members were among the first miRNAs found to be downregulated in cancer, and reduced let-7 expression is associated with poor patient prognosis $[68,69]$. Shortly after these discoveries, it was found that let-7 expression resulted in a significant decrease in lung cancer cell-line growth, indicating that let-7 plays an important role in controlling cellular growth in cancer cells [68] (Figure 1). let-7 downregulation also appears to be a common early event in the progression of ovarian cancer [70-77].

The identification of KRAS as a target of let-7 provided a mechanistic explanation for the role of this family of miRNAs in the regulation of cellular proliferation [69]. Indeed, antisense inhibition of let-7 resulted in elevated cancer cell proliferation, whereas let-7 overexpression in cancer cell lines, including lung cancer cell lines, resulted in cell-cycle arrest $[69,78]$. These observations in cell culture were echoed by in vivo studies that showed that let-7 could suppress tumor initiation in a NSCLC mouse model [78]. Importantly, mutations in let-7 complementary sites in NSCLC patients are associated with KRAS overexpression [79].

Beyond its role in the regulation of KRAS, let-7 targets other important genes that are involved in cellular growth and proliferation. HMGA2, which has been ascribed a putative oncogenic function, is targeted by let- 7 [80], as are several cell-cycle-related genes such as cyclin D2, CDK6, and CDC25A [81]. Intriguingly, let-7 can also directly downregulate Dicer, an endonuclease required for miRNA processing [82]. This raises the possibility that let-7 regulates not only the levels of key mRNAs for several cellular processes but also the global production

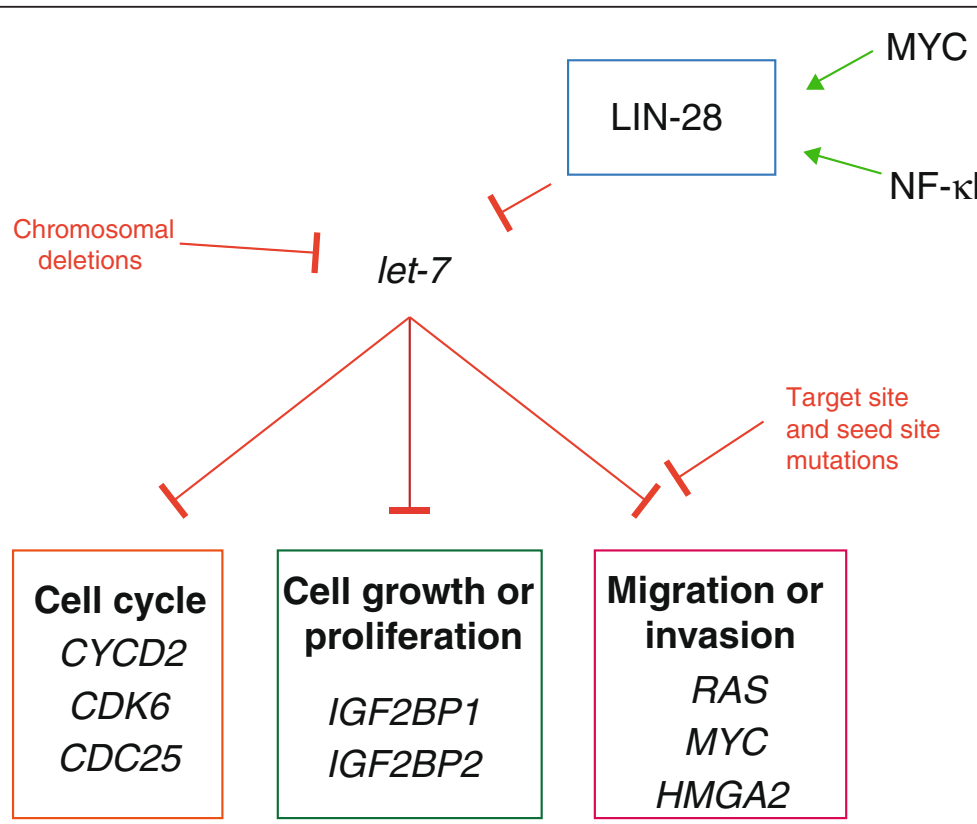

Figure 1 let-7 is a potent tumor suppressor microRNA. The let-7 microRNA (miRNA) can affect several key cellular pathways (such as those involved in the cell cycle, cell growth, cell proliferation, migration or invasion) by targeting key effector genes. In cancer, the function of let-7 is often lost or impaired through chromosomal deletions, mutations in the target sequence of regulated mRNAs, mutations in the seed site of the miRNA, or through post-transcriptional regulation by proteins such as LIN-28, whose expression is driven by potent oncogenes such as MYC and nuclear factor (NF)-KB. 
of miRNAs, with profound effects for virtually every aspect of cell growth, proliferation, signaling, and survival.

The function of let-7 in cancer has also been studied in the context of polymorphisms in the 3'UTR of mRNAs, which affect miRNA regulation by interfering with miRNA binding at target sites. Polymorphisms in the 3'UTR of KRAS mRNAs have been shown to inhibit let-7 function, and have been linked with poor patient prognosis in lung and breast cancers $[79,83]$. These findings further illustrate the dynamic and complex relationship between miRNAs and their targets, and provide a novel mechanism for altered miRNA function in cancer.

\section{$\operatorname{miR}-34$}

The miR-34 family genes, miR-34a and miR-34b/c, came into prominence as cancer-related genes after the discovery that they are under the direct transcriptional control of the key tumor suppressor p53, forming part of a transcriptional feedback loop that also involves E2F transcription factors (Figure 2). Specifically, p53 activation results in miR-34 expression, which in turn results in the direct downregulation of $E 2 F$ and the indirect upregulation of p53 by targeting SIRT1. Through this complex regulatory loop, miR-34 is able to regulate apoptosis initiation and the onset of cell-cycle arrest in cancer cell lines [84-88]. Intriguingly, it has been reported recently that loss of miR-34 expression does not affect cell-cycle arrest or apoptosis induced by $\mathrm{p} 53$, suggesting that the relationship between these genes is more complex than initially thought [89]. Studies have also revealed that
miR-34 plays an important role in regulating the survival of cancer cells after radiation and that it is able to radiosensitize breast cancer cells in vitro [90], suggesting a broader role for the interaction of p53 and miR-34 in the response to radiation.

miR-34 can target a variety of genes in cancer cells to regulate cell proliferation and survival. Several crucial cellcycle genes are targets of this family of miRNAs, including $C D C 25 A, C D K 4, C D K 6, c-M Y C$, and MET. Likewise, miR-34 modulates apoptosis by targeting key regulators of the apoptotic cascade, such as BCL-2, N-MYC, GMNN, and $H D A C 1$. These miRNAs are also able to induce senescence in cancer cells by targeting $c-M Y C, H D M X$, and SIRT1. Finally, miR-34-mediated repression of $W N T$, HMGA2, AXL, and SNAIL1 allows modulation of the migration and invasion properties of cancer cells, affecting the metastatic potential of tumors [88,91-93]. The ability of miR-34 to regulate a diverse set of biological processes makes it a potent and versatile cellular regulator, highlighting its importance in preventing the onset and progression of cancer.

\section{miR-15 and miR-16}

miR-15 and miR-16 are part of a cluster that was among the first to be implicated in cancer, when it was discovered that it is frequently deleted or downregulated in chronic lymphocytic leukemia (CLL) patients [94]. Further supporting a tumor-suppressor role for these miRNAs in CLL, deletion of the miR-15a-miR-16-1 cluster in mice causes development of phenotypes that

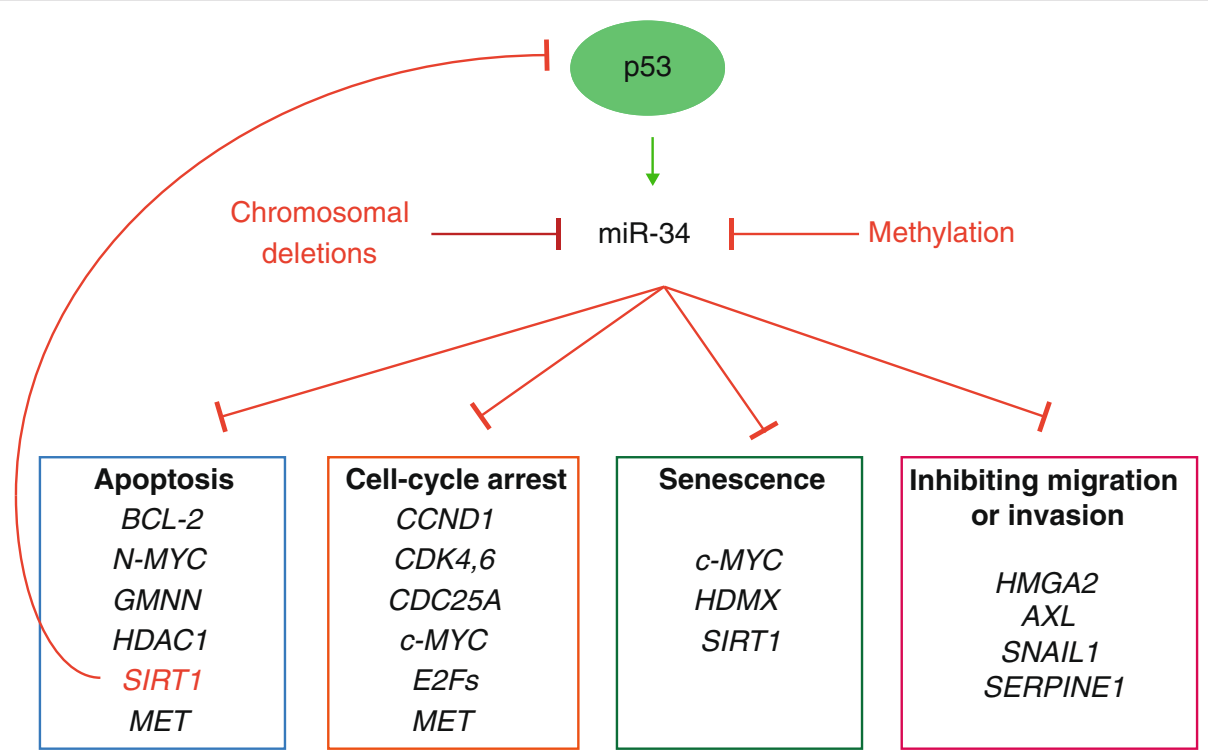

Figure 2 miR-34 can affect tumor initiation and progression by regulating a variety of key cellular functions. mir-34 is a transcriptional target of the tumor suppressor protein p53. This microRNA can regulate key genes involved in cell proliferation, survival, and invasion. In cancer, chromosomal aberrations can disrupt the mir-34 locus, and its transcription can also be inhibited by methylation changes and by inhibition or loss of p53. 
recapitulate CLL symptoms in humans [95]. In lung cancer, the miR-15-miR-16 cluster is also often deleted or downregulated [96], suggesting a role for these miRNAs in tumor suppression. Indeed, miR-15 and miR-16 are able to regulate many cellular processes involved in cell proliferation, survival, and migration by targeting key cellular signaling factors such as $B C L-2, C D C 2$, ETS1, $J U N, P D C D 4$ and WNT3A. miR-15 and miR-16 can also affect cell proliferation and invasion by targeting FGF-2 and FGFR1 [97]. Additionally, miR-15 and miR-16 can regulate Cyclin D1, Cyclin D2 and Cyclin E1, and miR-15 and miR-16 expression levels were inversely correlated with the levels of Cyclin D1 in NSCLC cell lines [98]. Together, these findings indicate that miR-15 and miR16 play broad roles in oncogenesis, affecting key cell proliferation and invasion systems.

\section{Inhibition of epithelial-to-mesenchymal transition: miR-200 and $\mathrm{miR}-205$}

The miR-200 family and miR-205 play important roles in the regulation of cancer cell proliferation and invasion by regulating $Z E B 1$ and ZEB2, two key promoters of EMT [99]. In lung cancer cells, overexpression of miR-200 resulted in decreased ZEB1 levels and elevated E-cadherin expression, suggesting loss of the regulatory activity of ZEB1 [100]. Mouse models support a role for these miRNAs in metastasis: miR-200 overexpression blocked the capacity of metastasis-prone tumor cells to undergo EMT and reduced the metastatic potential of these cells [101]. miRNA profiling of lung cancer cells has also suggested a role for these miRNAs in the regulation of EMT and invasion, indicating that multiple peptidases, cell adhesion proteins, extracellular matrix proteins, and cytoskeletal regulators are regulated by miR-200 [102].

Inhibition of oncogenes MCL1 and TCL1: miR-181 and miR-29 miR-181a and miR-181b are downregulated in gliomas and glioma cell lines [103]. Transfection of these miRNAs in cell culture resulted in the inhibition of cellular growth and invasion, accompanied by increased apoptosis. In addition, transfected cells were impaired in their ability to grow in an anchorage-independent manner, suggesting that miR-181a and miR-181b may also play important roles in preventing tumor invasiveness [103]. Efforts to identify the targets of miRNAs that are involved in leukemia or lymphoma have revealed that miR-181 acts as a tumor suppressor by targeting the TCL1 oncogene. Moreover, this miRNA can indirectly regulate the levels of the oncogene $M C L 1$, further modulating the apoptotic potential of CLL cancer cells by controlling cellular survival [104].

miR-29 is another miRNA that is often expressed at aberrant levels in cancers, including CLL, hepatocellular carcinoma, and breast cancer [105-107]. Like miR-181, mir-29 targets the oncogenes MCL1 and TCL1 [108]. miR-29 also targets genes that regulate cellular survival, such as CDK6 and KLF4, as well as long non-coding RNAs such as MEG3 [105,108,109]. Interestingly, miR29 was found to indirectly target the de novo DNA methyltransferases DNMT1, DNMT3A and DNMT3b, thereby controlling gene expression [108]. Loss of miR29, therefore, may result in elevated MCL1 and DNMT expression, causing the increased cell survival seen in acute myeloid leukemia [110-112].

\section{Clinical and therapeutic implications: microRNAs as biomarkers, therapeutic targets and targeted therapeutics}

miRNAs play important and diverse roles in the initiation and progression of a wide variety of cancers. By modulating the expression of key regulators of cellular proliferation, growth, survival, and signaling, miRNAs can act as potent oncogenes and tumor suppressors. Moreover, it has become increasingly clear that miRNAs are integral elements in a number of crucial gene expression networks, acting in tightly regulated feedback loops that are often disrupted in cancer.

Recent technical advances in the methods used to examine miRNA expression from a wide variety of tissues, including the development of reliable qPCR reagents and high-throughput qPCR systems, improvements in microarray-based methods, and the increased accessibility of next-generation sequencing systems for miRNA profiling, have made the prospect of using miRNAs as biomarkers a feasible and attractive option. Because of their small size, miRNAs are more stable than mRNAs; this allows for expression profiling using a variety of tissue sources, including frozen, fixed, and paraffin-embedded tissues, as well as blood and several other biological fluids. Notably, miRNA profiles can not only distinguish between normal and cancerous tissue but also establish tissue of origin and cancer subtype [113-117]. A recent example of the value of miRNA profiling in the clinical setting comes from a study in CLL patients, which found that miR-155 levels in B cells can distinguish individuals with CLL from patients with monoclonal B-cell lymphocytosis, and can distinguish both of these groups from healthy individuals. Furthermore, this study found that patients who failed to respond to a standard chemotherapeutic regime had higher pre-treatment levels of miR-155 than patients who responded favorably, illustrating the prognostic value of miRNAs [118].

Currently, the main challenges to the use of miRNAs as biomarkers are technical, including lack of consistency between studies and variations in control usage and normalization [116,117]. We predict that as these obstacles are surmounted, the use of miRNAs as clinical biomarkers will become routine. 
miRNAs are also attractive both as therapeutic targets and as therapeutic agents themselves. A number of strategies to harness miRNAs as therapeutics in cancer have been attempted, but they are generally based on the introduction of oligonucleotides to supplement the cellular expression of tumor suppressor miRNAs, or of antisense oligonucleotides to ablate the action of oncogenic miRNAs. This approach allows the specific targeting of individual miRNAs or miRNA families, but effective and stable oligonucleotide delivery remains a major hurdle [119]. Promising advances have been made through the use of modified oligonucleotides and novel biodelivery methods, and the field is expected to progress rapidly in its movement towards viable miRNA-based therapeutics.

The varied and important roles of miR-34 in cancer make it an attractive candidate as a therapeutic agent. While the field of miRNA-based therapeutics is in its early stages, recent studies show promising results that support the feasibility of this novel therapeutic modality. In one such study, Trang and colleagues [120] used a novel lipid emulsion to systemically deliver a synthetic miR-34a mimic in a Kras-activated autochtonous model of NSCLC, resulting in a significant decrease in tumor burden. This study underscores the enormous therapeutic potential of miRNAs in cancer, both as targets and as therapeutic agents.

Another important application for miRNAs in the clinic is in the alteration of the chemotherapeutic response during treatment. Because tumors are able to exploit a variety of signaling pathways and molecular mechanisms to mediate their enhanced proliferation and survival, they often develop resistance to chemotherapeutic agents, which tend to target single pathways or biological processes. As miRNAs can act as potent regulators of multiple key cellular pathways, miRNA supplementation or silencing is a promising approach to potentiate the effects of chemotherapy. While this application of miRNAs is still in its early stages, recent studies suggest that targeting miR-21 and miR-1 (which plays a tumor-suppressor role in the lung) can sensitize cancer cells to chemotherapy $[121,122]$. Similarly, a role for miRNAs in the response to radiotherapy can be easily envisioned, given that miRNAs play important roles in the regulation of cell survival and apoptosis in response to DNA damage.

The use of miRNAs in the clinic is in its infancy. Nevertheless, there are a number of trials currently underway, focusing largely on the use of miRNAs as biomarkers [123]. Significant obstacles to the widespread adoption of miRNAs as clinical agents remain, particularly regarding toxicity, specificity and delivery [124]. Despite its many challenges, this area of scientific and pharmaceutical development is expected to see enormous advances in the next few years, bringing to the clinic a wholly novel class of therapeutics for the treatment of cancer.

\section{Abbreviations}

BCL: B-cell lymphoma; CLL: Chronic lymphocytic leukemia; EGFR: Epidermal growth factor receptor; EMT: Epithelial-to-mesenchymal transition; miRNA: microRNA; NSCLC: Non-small cell lung cancer; p-EGFR: Phosphorylated EGFR; qPCR: Quantitative polymerase chain reaction; UTR: Untranslated region.

\section{Competing interests}

The authors declare that they have no competing interests.

\section{Acknowledgements}

The authors would like to thank members of the Slack Lab for their helpful discussions and suggestions. This work was supported by grants from the $\mathrm{NIH}$, the Lungevity Foundation and funds from the Yale Cancer Center.

Published: 30 December 2013

\section{References}

1. Esquela-Kerscher A, Slack FJ: Oncomirs - microRNAs with a role in cancer. Nat Rev Cancer 2006, 6:259-269.

2. Calin GA, Croce CM: MicroRNA signatures in human cancers. Nat Rev Cancer 2006, 6:857-866.

3. Calin GA, Sevignani C, Dumitru CD, Hyslop T, Noch E, Yendamuri S, Shimizu M, Rattan S, Bullrich F, Negrini M, Croce CM: Human microRNA genes are frequently located at fragile sites and genomic regions involved in cancers. Proc Natl Acad Sci U S A 2004, 101:2999-3004.

4. Bartel DP: MicroRNAs: genomics, biogenesis, mechanism, and function. Cell 2004, 116:281-297.

5. Pasquinelli AE, Hunter S, Bracht J: MicroRNAs: a developing story. Curr Opin Genet Dev 2005, 15:200-205.

6. Lim LP, Lau NC, Garrett-Engele P, Grimson A, Schelter JM, Castle J, Bartel DP, Linsley PS, Johnson JM: Microarray analysis shows that some microRNAs downregulate large numbers of target mRNAs. Nature 2005, 433:769-773.

7. Krek A, Grun D, Poy MN, Wolf R, Rosenberg L, Epstein EJ, MacMenamin P, da Piedade I, Gunsalus KC, Stoffel M, Rajewsky N: Combinatorial microRNA target predictions. Nat Genet 2005, 37:495-500.

8. John B, Enright AJ, Aravin A, Tuschl T, Sander C, Marks DS: Human microRNA targets. PLOS Biol 2004, 2:e363.

9. Chugh P, Dittmer DP: Potential pitfalls in microRNA profiling. Wiley Interdiscip Rev RNA 2012, 3:601-616.

10. Moltzahn F, Olshen AB, Baehner L, Peek A, Fong L, Stoppler H, Simko J, Hilton JF, Carroll P, Blelloch R: Microfluidic-based multiplex qRT-PCR identifies diagnostic and prognostic microRNA signatures in the sera of prostate cancer patients. Cancer Res 2011, 71:550-560.

11. Jang JS, Simon VA, Feddersen RM, Rakhshan F, Schultz DA, Zschunke MA, Lingle WL, Kolbert CP, Jen J: Quantitative miRNA expression analysis using fluidigm microfluidics dynamic arrays. BMC Genomics 2011, 12:144.

12. Stahlberg A, Kubista M, Pfaffl M: Comparison of reverse transcriptases in gene expression analysis. Clin Chem 2004, 50:1678-1680.

13. Kitchen RR, Kubista M, Tichopad A: Statistical aspects of quantitative realtime PCR experiment design. Methods 2010, 50:231-236.

14. Kim VN, Nam JW: Genomics of microRNA. Trends Genet 2006, 22:165-173.

15. Hammond SM: microRNA detection comes of age. Nat Method 2006, 3:12-13.

16. Duan D, Zheng KX, Shen Y, Cao R, Jiang L, Lu Z, Yan X, Li J: Label-free high-throughput microRNA expression profiling from total RNA. Nucleic Acids Res 2011, 39:e154.

17. Cortez MA, Bueso-Ramos C, Ferdin J, Lopez-Berestein G, Sood AK, Calin GA: MicroRNAs in body fluids - the mix of hormones and biomarkers. Nat Rev Clin Oncol 2011, 8:467-477.

18. Weber JA, Baxter DH, Zhang S, Huang DY, Huang KH, Lee MJ, Galas DJ, Wang K: The microRNA spectrum in 12 body fluids. Clin Chem 2010, 56:1733-1741

19. Olive V, Jiang I, He L: mir-17-92, a cluster of miRNAs in the midst of the cancer network. Int J Biochem Cell Biol 2010, 42:1348-1354.

20. Tanzer A, Stadler PF: Molecular evolution of a microRNA cluster. J Mol Biol 2004, 339:327-335.

21. Conkrite K, Sundby M, Mukai S, Thomson JM, Mu D, Hammond SM, MacPherson D: miR-17 92 cooperates with RB pathway mutations to promote retinoblastoma. Genes Dev 2011, 25:1734-1745. 
22. Ernst A, Campos B, Meier J, Devens F, Liesenberg F, Wolter M, Reifenberger G, Herold-Mende C, Lichter P, Radlwimmer B: De-repression of CTGF via the miR-17-92 cluster upon differentiation of human glioblastoma spheroid cultures. Oncogene 2010, 29:3411-3422.

23. Hayashita Y, Osada H, Tatematsu Y, Yamada H, Yanagisawa K, Tomida S, Yatabe Y, Kawahara K, Sekido Y, Takahashi T: A polycistronic microRNA cluster, miR-17-92, is overexpressed in human lung cancers and enhances cell proliferation. Cancer Res 2005, 65:9628-9632.

24. Kim K, Chadalapaka G, Lee SO, Yamada D, Sastre-Garau X, Defossez PA, Park YY, Lee JS, Safe S: Identification of oncogenic microRNA-17-92/ZBTB4/ specificity protein axis in breast cancer. Oncogene 2012, 31:1034-1044.

25. Yu J, Ohuchida K, Mizumoto K, Fujita H, Nakata K, Tanaka M: MicroRNA miR-17-5p is overexpressed in pancreatic cancer, associated with a poor prognosis, and involved in cancer cell proliferation and invasion. Cancer Biol Ther 2010, 10:748-757.

26. Volinia S, Calin GA, Liu CG, Ambs S, Cimmino A, Petrocca F, Visone R, lorio M, Roldo C, Ferracin M, Prueitt RL, Yanaihara N, Lanza G, Scarpa A Vecchione A, Negrini M, Harris CC, Croce CM: A microRNA expression signature of human solid tumors defines cancer gene targets. Proc Natl Acad Sci U S A 2006, 103:2257-2261.

27. Mendell JT: miRiad roles for the miR-17-92 cluster in development and disease. Cell 2008, 133:217-222.

28. Sylvestre Y, De Guire V, Querido E, Mukhopadhyay UK, Bourdeau V, Major F, Ferbeyre G, Chartrand P: An E2F/miR-20a autoregulatory feedback loop. J Biol Chem 2007, 282:2135-2143.

29. O'Donnell KA, Wentzel EA, Zeller Kl, Dang CV, Mendell JT: c-Myc-regulated microRNAs modulate E2F1 expression. Nature 2005, 435:839-843.

30. Taguchi A, Yanagisawa K, Tanaka M, Cao K, Matsuyama Y, Goto H, Takahashi $\mathrm{T}$ : Identification of hypoxia-inducible factor-1 alpha as a novel target for miR-17-92 microRNA cluster. Cancer Res 2008, 68:5540-5545.

31. Dews M, Homayouni A, Yu D, Murphy D, Sevignani C, Wentzel E, Furth EE, Lee WM, Enders GH, Mendell JT, Thomas-Tikhonenko A: Augmentation of tumor angiogenesis by a Myc-activated microRNA cluster. Nat Genet 2006, 38:1060-1065.

32. Xiao C, Srinivasan L, Calado DP, Patterson HC, Zhang B, Wang J, Henderson $J M$, Kutok JL, Rajewsky K: Lymphoproliferative disease and autoimmunity in mice with increased miR-17-92 expression in lymphocytes. Nat Immunol 2008, 9:405-414.

33. Liu M, Wang Z, Yang S, Zhang W, He S, Hu C, Zhu H, Quan L, Bai J, Xu N: TNF-alpha is a novel target of miR-19a. Int J Oncol 2011, 38:1013-1022.

34. Olive V, Bennett MJ, Walker JC, Ma C, Jiang I, Cordon-Cardo C, Li QJ, Lowe SW, Hannon GJ, He L: miR-19 is a key oncogenic component of mir-17-92. Genes Dev 2009, 23:2839-2849.

35. Mu P, Han YC, Betel $D$, Yao E, Squatrito M, Ogrodowski $P$, de Stanchina $E$, D'Andrea A, Sander C, Ventura A: Genetic dissection of the miR-17 92 cluster of microRNAs in Myc-induced B-cell lymphomas. Genes Dev 2009, 23:2806-2811.

36. Trimarchi JM, Lees JA: Sibling rivalry in the E2F family. Nat Rev Mol Cell Biol 2002, 3:11-20.

37. Seike M, Goto A, Okano T, Bowman ED, Schetter AJ, Horikawa I, Mathe EA, Jen J, Yang P, Sugimura H, Gemma A, Kudoh S, Croce CM, Harris CC: MiR-21 is an EGFR-regulated anti-apoptotic factor in lung cancer in neversmokers. Proc Natl Acad Sci U S A 2009, 106:12085-12090.

38. Hatley ME, Patrick DM, Garcia MR, Richardson JA, Bassel-Duby R, van Rooij E, Olson EN: Modulation of K-Ras-dependent lung tumorigenesis by MicroRNA-21. Cancer Cell 2010, 18:282-293.

39. Zhang JG, Wang JJ, Zhao F, Liu Q, Jiang K, Yang GH: MicroRNA-21 (miR-21) represses tumor suppressor PTEN and promotes growth and invasion in non-small cell lung cancer (NSCLC). Clinica Chim Acta 2010, 411:846-852.

40. Frezzetti D, De Menna M, Zoppoli P, Guerra C, Ferraro A, Bello AM, De Luca P, Calabrese C, Fusco A, Ceccarelli M, Zollo M, Barbacid M, Di Lauro R, De Vita G: Upregulation of miR-21 by Ras in vivo and its role in tumor growth. Oncogene 2011, 30:275-286.

41. Fei J, Lan F, Guo M, Li Y, Liu Y: Inhibitory effects of anti-miRNA oligonucleotides (AMOs) on A549 cell growth. J Drug Target 2008, 16:688-693.

42. Iorio MV, Ferracin M, Liu CG, Veronese A, Spizzo R, Sabbioni S, Magri E, Pedriali M, Fabbri M, Campiglio M, Ménard S, Palazzo JP, Rosenberg A, Musiani P, Volinia S, Nenci I, Calin GA, Querzoli P, Negrini M, Croce CM: MicroRNA gene expression deregulation in human breast cancer. Cancer Res 2005, 65:7065-7070.
43. Zhu S, Si ML, Wu H, Mo YY: MicroRNA-21 targets the tumor suppressor gene tropomyosin 1 (TPM1). J Biol Chem 2007, 282:14328-14336.

44. Chan JA, Krichevsky AM, Kosik KS: MicroRNA-21 is an antiapoptotic factor in human glioblastoma cells. Cancer Res 2005, 65:6029-6033.

45. Conti A, Aguennouz M, La Torre D, Tomasello C, Cardali S, Angileri FF, Maio F, Cama A, Germano A, Vita G, Tomasello F: miR-21 and 221 upregulation and miR-181b downregulation in human grade II-IV astrocytic tumors. J Neurooncol 2009, 93:325-332.

46. Gabriely G, Wurdinger T, Kesari S, Esau CC, Burchard J, Linsley PS, Krichevsky AM: MicroRNA 21 promotes glioma invasion by targeting matrix metalloproteinase regulators. Mol Cell Biol 2008, 28:5369-5380.

47. Papagiannakopoulos T, Shapiro A, Kosik KS: MicroRNA-21 targets a network of key tumor-suppressive pathways in glioblastoma cells. Cancer Res 2008, 68:8164-8172.

48. Silber J, Lim DA, Petritsch C, Persson Al, Maunakea AK, Yu M, Vandenberg SR, Ginzinger DG, James CD, Costello JF, Bergers G, Weiss WA, Alvarez-Buylla A, Hodgson JG: miR-124 and miR-137 inhibit proliferation of glioblastoma multiforme cells and induce differentiation of brain tumor stem cells. BMC Med 2008, 6:14

49. Meng F, Henson R, Wehbe-Janek H, Ghoshal K, Jacob ST, Patel T: MicroRNA-21 regulates expression of the PTEN tumor suppressor gene in human hepatocellular cancer. Gastroenterology 2007, 133:647-658.

50. Zhu S, Wu H, Wu F, Nie D, Sheng S, Mo YY: MicroRNA-21 targets tumor suppressor genes in invasion and metastasis. Cell Res 2008, 18:350-359.

51. Asangani IA, Rasheed SA, Nikolova DA, Leupold JH, Colburn NH, Post S, Allgayer $\mathrm{H}$ : MicroRNA-21 (miR-21) post-transcriptionally downregulates tumor suppressor Pdcd4 and stimulates invasion, intravasation and metastasis in colorectal cancer. Oncogene 2008, 27:2128-2136.

52. Nakada M, Okada Y, Yamashita J: The role of matrix metalloproteinases in glioma invasion. Front Biosci 2003, 8:e261-e269.

53. Medina PP, Nolde M, Slack FJ: OncomiR addiction in an in vivo model of microRNA-21-induced pre-B-cell lymphoma. Nature 2010, 467:86-90.

54. Yanaihara N, Caplen N, Bowman E, Seike M, Kumamoto K, Yi M, Stephens RM, Okamoto A, Yokota J, Tanaka T, Calin GA, Liu CG, Croce CM, Harris CC: Unique microRNA molecular profiles in lung cancer diagnosis and prognosis. Cancer Cell 2006, 9:189-198.

55. Donnem T, Eklo K, Berg T, Sorbye SW, Lonvik K, Al-Saad S, Al-Shibli K, Andersen S, Stenvold H, Bremnes RM, Busund LT: Prognostic impact of MiR-155 in non-small cell lung cancer evaluated by in situ hybridization. J Transl Med 2011, 9:6.

56. Costinean S, Zanesi N, Pekarsky Y, Tili E, Volinia S, Heerema N, Croce CM: Pre-B cell proliferation and lymphoblastic leukemia/high-grade lymphoma in E(mu)-miR155 transgenic mice. Proc Natl Acad Sci U S A 2006, 103:7024-7029.

57. Babar IA, Cheng CJ, Booth CJ, Liang X, Weidhaas JB, Saltzman WM, Slack FJ: Nanoparticle-based therapy in an in vivo microRNA-155 (miR-155)dependent mouse model of lymphoma. Proc Natl Acad Sci U S A 2012, 109:E1695-E1704.

58. Babar IA, Czochor J, Steinmetz A, Weidhaas JB, Glazer PM, Slack FJ: Inhibition of hypoxia-induced miR-155 radiosensitizes hypoxic lung cancer cells. Cancer Biol Ther 2011, 12:908-914.

59. Jiang $\mathrm{S}$, Zhang HW, Lu MH, He XH, Li Y, Gu H, Liu MF, Wang ED: MicroRNA-155 functions as an OncomiR in breast cancer by targeting the suppressor of cytokine signaling 1 gene. Cancer Res 2010, 70:3119-3127.

60. Kong W, He L, Coppola M, Guo J, Esposito NN, Coppola D, Cheng JQ: MicroRNA-155 regulates cell survival, growth, and chemosensitivity by targeting FOXO3a in breast cancer. J Biol Chem 2010, 285:17869-17879.

61. Kong W, Yang H, He L, Zhao JJ, Coppola D, Dalton WS, Cheng JQ: MicroRNA-155 is regulated by the transforming growth factor beta/ Smad pathway and contributes to epithelial cell plasticity by targeting RhoA. Mol Cell Biol 2008, 28:6773-6784.

62. Garofalo M, Di Leva G, Romano G, Nuovo G, Suh SS, Ngankeu A, Taccioli C, Pichiorri F, Alder H, Secchiero P, Gasparini P, Gonelli A, Costinean S, Acunzo $M$, Condorelli G, Croce CM: miR-221\&222 regulate TRAIL resistance and enhance tumorigenicity through PTEN and TIMP3 downregulation. Cancer Cell 2009, 16:498-509.

63. Garofalo M, Quintavalle C, Di Leva G, Zanca C, Romano G, Taccioli C, Liu CG, Croce CM, Condorelli G: MicroRNA signatures of TRAIL resistance in human non-small cell lung cancer. Oncogene 2008, 27:3845-3855.

64. Zhang C, Zhang J, Zhang A, Wang Y, Han L, You Y, Pu P, Kang C: PUMA is a novel target of miR-221/222 in human epithelial cancers. Int J Oncol 2010, 37:1621-1626. 
65. Lukiw WJ, Cui JG, Li YY, Culicchia F: Up-regulation of micro-RNA-221 (miRNA-221; chr Xp11.3) and caspase-3 accompanies down-regulation of the survivin-1 homolog BIRC1 (NAIP) in glioblastoma multiforme (GBM). J Neurooncol 2009, 91:27-32.

66. Ciafre SA, Galardi S, Mangiola A, Ferracin M, Liu CG, Sabatino G, Negrini M, Maira G, Croce CM, Farace MG: Extensive modulation of a set of microRNAs in primary glioblastoma. Biochem Biophys Res Commun 2005, 334:1351-1358.

67. Gillies JK, Lorimer IA: Regulation of p27Kip1 by miRNA 221/222 in glioblastoma. Cell Cycle 2007, 6:2005-2009.

68. Takamizawa J, Konishi H, Yanagisawa K, Tomida S, Osada H, Endoh H, Harano T, Yatabe Y, Nagino M, Nimura Y, Mitsudomi T, Takahashi T: Reduced expression of the let-7 microRNAs in human lung cancers in association with shortened postoperative survival. Cancer Res 2004, 64:3753-3756.

69. Johnson SM, Grosshans H, Shingara J, Byrom M, Jarvis R, Cheng A, Labourier E, Reinert KL, Brown D, Slack FJ: RAS is regulated by the let-7 microRNA family. Cell 2005, 120:635-647.

70. Zhang L, Huang J, Yang N, Greshock J, Megraw MS, Giannakakis A, Liang S, Naylor TL, Barchetti A, Ward MR, Yao G, Medina A, O'Brien-Jenkins A, Katsaros D, Hatzigeorgiou A, Gimotty PA, Weber BL, Coukos G: microRNAs exhibit high frequency genomic alterations in human cancer. Proc Natl Acad Sci U S A 2006, 103:9136-9141.

71. Zhang L, Volinia S, Bonome T, Calin GA, Greshock J, Yang N, Liu CG, Giannakakis A, Alexiou P, Hasegawa K, Johnstone CN, Megraw MS, Adams S, Lassus H, Huang J, Kaur S, Liang S, Sethupathy P, Leminen A, Simossis VA, Sandaltzopoulos R, Naomoto Y, Katsaros D, Gimotty PA, DeMichele A, Huang Q, Bützow R, Rustgi AK, Weber BL, Birrer MJ, et al: Genomic and epigenetic alterations deregulate microRNA expression in human epithelial ovarian cancer. Proc Natl Acad Sci U S A 2008, 105:7004-7009.

72. Iorio MV, Visone R, Di Leva G, Donati V, Petrocca F, Casalini P, Taccioli C, Volinia S, Liu CG, Alder H, Calin GA, Ménard S, Croce CM: MicroRNA signatures in human ovarian cancer. Cancer Res 2007, 67:8699-8707.

73. Nam EJ, Yoon H, Kim SW, Kim H, Kim YT, Kim JH, Kim JW, Kim S: MicroRNA expression profiles in serous ovarian carcinoma. Clin Cancer Res 2008, 14:2690-2695.

74. Dahiya N, Sherman-Baust CA, Wang TL, Davidson B, Shih le M, Zhang Y, Wood W III, Becker KG, Morin PJ: MicroRNA expression and identification of putative miRNA targets in ovarian cancer. PLoS One 2008, 3:e2436.

75. Wyman SK, Parkin RK, Mitchell PS, Fritz BR, O'Briant K, Godwin AK, Urban N, Drescher CW, Knudsen BS, Tewari M: Repertoire of microRNAs in epithelial ovarian cancer as determined by next generation sequencing of small RNA cDNA libraries. PLoS One 2009, 4:e5311.

76. Lee CH, Subramanian S, Beck AH, Espinosa I, Senz J, Zhu SX, Huntsman D, van de Rijn M, Gilks CB: MicroRNA profiling of BRCA1/2 mutation-carrying and non-mutation-carrying high-grade serous carcinomas of ovary. PLOS One 2009, 4:e7314

77. Yang H, Kong W, He L, Zhao JJ, O'Donnell JD, Wang J, Wenham RM, Coppola D, Kruk PA, Nicosia SV, Cheng JQ: MicroRNA expression profiling in human ovarian cancer: miR-214 induces cell survival and cisplatin resistance by targeting PTEN. Cancer Res 2008, 68:425-433.

78. Kumar MS, Erkeland SJ, Pester RE, Chen CY, Ebert MS, Sharp PA, Jacks T: Suppression of non-small cell lung tumor development by the let-7 microRNA family. Proc Natl Acad Sci U S A 2008, 105:3903-3908.

79. Chin L, Ratner E, Leng S, Zhai R, Nallur S, Babar I, Muller RU, Straka E, Su L, Burki EA, Crowell RE, Patel R, Kulkarni T, Homer R, Zelterman D, Kidd KK, Zhu Y, Christiani DC, Belinsky SA, Slack FJ, Weidhaas JB: A SNP in a let-7 microRNA complementary site in the KRAS $3^{\prime}$ untranslated region increases non-small cell lung cancer risk. Cancer Res 2008, 68:8535-8540.

80. Lee YS, Dutta A: The tumor suppressor microRNA let-7 represses the HMGA2 oncogene. Genes Dev 2007, 21:1025-1030.

81. Johnson CD, Esquela-Kerscher A, Stefani G, Byrom M, Kelnar K, Ovcharenko D, Wilson M, Wang X, Shelton J, Shingara J, Chin L, Brown D, Slack FJ: The let-7 microRNA represses cell proliferation pathways in human cells. Cancer Res 2007, 67:7713-7722.

82. Tokumaru S, Suzuki M, Yamada H, Nagino M, Takahashi T: let-7 regulates Dicer expression and constitutes a negative feedback loop. Carcinogenesis 2008, 29:2073-2077.

83. Paranjape $T$, Heneghan $H$, Lindner R, Keane FK, Hoffman A, Hollestelle A, Dorairaj J, Geyda K, Pelletier C, Nallur S, Martens JW, Hooning MJ, Kerin M, Zelterman D, Zhu Y, Tuck D, Harris L, Miller N, Slack F, Weidhaas J:
A 3'-untranslated region KRAS variant and triple-negative breast cancer: a case-control and genetic analysis. Lancet Oncol 2011, 12:377-386.

84. Chang TC, Wentzel EA, Kent OA, Ramachandran K, Mullendore M, Lee KH Feldmann G, Yamakuchi M, Ferlito M, Lowenstein CJ, Arking DE, Beer MA, Maitra A, Mendell JT: Transactivation of miR-34a by p53 broadly influences gene expression and promotes apoptosis. Mol Cell 2007, 26:745-752.

85. Raver-Shapira N, Marciano E, Meiri E, Spector Y, Rosenfeld N, Moskovits N, Bentwich Z, Oren M: Transcriptional activation of miR-34a contributes to p53-mediated apoptosis. Mol Cell 2007, 26:731-743.

86. Tarasov V, Jung P, Verdoodt B, Lodygin D, Epanchintsev A, Menssen A, Meister $G$, Hermeking H: Differential regulation of microRNAs by $p 53$ revealed by massively parallel sequencing: miR-34a is a p53 target that induces apoptosis and G1-arrest. Cell Cycle 2007, 6:1586-1593.

87. He L, He X, Lim LP, de Stanchina E, Xuan Z, Liang Y, Xue W, Zender L, Magnus J, Ridzon D, Jackson AL, Linsley PS, Chen C, Lowe SW, Cleary MA, Hannon GJ: A microRNA component of the p53 tumour suppressor network. Nature 2007, 447:1130-1134.

88. Kim NH, Kim HS, Li XY, Lee I, Choi HS, Kang SE, Cha SY, Ryu JK, Yoon D, Fearon ER, Rowe RG, Lee S, Maher CA, Weiss SJ, Yook Jl: A p53/miRNA-34 axis regulates Snail1-dependent cancer cell epithelial-mesenchymal transition. J Cell Biol 2011, 195:417-433.

89. Concepcion CP, Han YC, Mu P, Bonetti C, Yao E, D'Andrea A, Vidigal JA, Maughan WP, Ogrodowski P, Ventura A: Intact p53-dependent responses in miR-34-deficient mice. PLoS Genet 2012, 8:e1002797.

90. Kato M, Paranjape T, Muller RU, Nallur S, Gillespie E, Keane K, EsquelaKerscher A, Weidhaas JB, Slack FJ: The mir-34 microRNA is required for the DNA damage response in vivo in C. elegans and in vitro in human breast cancer cells. Oncogene 2009, 28:2419-2424.

91. Lize M, Klimke A, Dobbelstein M: MicroRNA-449 in cell fate determination. Cell Cycle 2011, 10:2874-2882.

92. Mudduluru G, Ceppi P, Kumarswamy R, Scagliotti GV, Papotti M, Allgayer H: Regulation of Axl receptor tyrosine kinase expression by miR-34a and miR-199a/b in solid cancer. Oncogene 2011, 30:2888-2899.

93. Muth M, Hussein K, Jacobi C, Kreipe H, Bock O: Hypoxia-induced down-regulation of microRNA-449a/b impairs control over targeted SERPINE1 (PAI-1) mRNA - a mechanism involved in SERPINE1 (PAI-1) overexpression. J Transl Med 2011, 9:24.

94. Calin GA, Dumitru CD, Shimizu M, Bichi R, Zupo S, Noch E, Aldler H, Rattan S, Keating M, Rai K, Rassenti L, Kipps T, Negrini M, Bullrich F, Croce CM: Frequent deletions and down-regulation of micro-RNA genes miR15 and miR16 at 13q14 in chronic lymphocytic leukemia. Proc Natl Acad Sci U S A 2002, 99:15524-15529.

95. Klein U, Lia M, Crespo M, Siegel R, Shen Q, Mo T, Ambesi-Impiombato A, Califano A, Migliazza A, Bhagat G, Dalla-Favera R: The DLEU2/miR-15a/16-1 cluster controls B cell proliferation and its deletion leads to chronic lymphocytic leukemia. Cancer Cell 2010, 17:28-40.

96. Bandi N, Zbinden S, Gugger M, Arnold M, Kocher V, Hasan L, Kappeler A Brunner T, Vassella E: miR-15a and miR-16 are implicated in cell cycle regulation in a $\mathrm{Rb}$-dependent manner and are frequently deleted or down-regulated in non-small cell lung cancer. Cancer Res 2009, 69:5553-5559

97. Musumeci M, Coppola V, Addario A, Patrizii M, Maugeri-Sacca M, Memeo L, Colarossi C, Francescangeli F, Biffoni M, Collura D, Giacobbe A, D'Urso L, Falchi M, Venneri MA, Muto G, De Maria R, Bonci D: Control of tumor and microenvironment cross-talk by miR-15a and miR-16 in prostate cancer. Oncogene 2011, 30:4231-4242.

98. Bandi N, Vassella E: miR-34a and miR-15a/16 are co-regulated in nonsmall cell lung cancer and control cell cycle progression in a synergistic and Rb-dependent manner. Mol Cancer 2011, 10:55.

99. Gregory PA, Bert AG, Paterson EL, Barry SC, Tsykin A, Farshid G, Vadas MA, Khew-Goodall Y, Goodall GJ: The miR-200 family and miR-205 regulate epithelial to mesenchymal transition by targeting ZEB1 and SIP1. Nat Cell Biol 2008, 10:593-601.

100. Hurteau GJ, Carlson JA, Spivack SD, Brock GJ: Overexpression of the microRNA hsa-miR-200c leads to reduced expression of transcription factor 8 and increased expression of E-cadherin. Cancer Res 2007, 67:7972-7976

101. Gibbons DL, Lin W, Creighton CJ, Rizvi ZH, Gregory PA, Goodall GJ, Thilaganathan N, Du L, Zhang Y, Pertsemlidis A, Kurie JM: Contextual extracellular cues promote tumor cell EMT and metastasis by regulating miR-200 family expression. Genes Dev 2009, 23:2140-2151. 
102. Schliekelman MJ, Gibbons DL, Faca VM, Creighton CJ, Rizvi ZH, Zhang Q, Wong $\mathrm{CH}$, Wang $\mathrm{H}$, Ungewiss $\mathrm{C}$, Ahn $\mathrm{YH}$, Shin DH, Kurie JM, Hanash SM: Targets of the tumor suppressor miR-200 in regulation of the epithelial-mesenchymal transition in cancer. Cancer Res 2011 , 71:7670-7682

103. Shi L, Cheng Z, Zhang J, Li R, Zhao P, Fu Z, You Y: hsa-mir-181a and hsa-mir-181b function as tumor suppressors in human glioma cells. Brain Res 2008, 1236:185-193.

104. Cimmino A, Calin GA, Fabbri M, lorio MV, Ferracin M, Shimizu M, Wojcik SE, Aqeilan Rl, Zupo S, Dono M, Rassenti L, Alder H, Volinia S, Liu CG, Kipps TJ, Negrini M, Croce CM: miR-15 and miR-16 induce apoptosis by targeting BCL2. Proc Natl Acad Sci U S A 2005, 102:13944-13949.

105. Cittelly DM, Finlay-Schultz J, Howe EN, Spoelstra NS, Axlund SD, Hendricks P, Jacobsen BM, Sartorius CA, Richer JK: Progestin suppression of miR-29 potentiates dedifferentiation of breast cancer cells via KLF4. Oncogene 2013, 32:2555-2564.

106. Pekarsky Y, Santanam U, Cimmino A, Palamarchuk A, Efanov A, Maximov V, Volinia S, Alder H, Liu CG, Rassenti L, Calin GA, Hagan JP, Kipps T, Croce CM: Tcl1 expression in chronic lymphocytic leukemia is regulated by miR-29 and miR-181. Cancer Res 2006, 66:11590-11593.

107. Xiong Y, Fang JH, Yun JP, Yang J, Zhang Y, Jia WH, Zhuang SM: Effects of microRNA-29 on apoptosis, tumorigenicity, and prognosis of hepatocellular carcinoma. Hepatology 2010, 51:836-845

108. Mott JL, Kobayashi S, Bronk SF, Gores GJ: mir-29 regulates $\mathrm{Mcl}-1$ protein expression and apoptosis. Oncogene 2007, 26:6133-6140.

109. Zhao J, Lin J, Lwin T, Yang H, Guo J, Kong W, Dessureault S, Moscinski LC, Rezania D, Dalton WS, Sotomayor E, Tao J, Cheng JQ: microRNA expression profile and identification of miR-29 as a prognostic marker and pathogenetic factor by targeting CDK6 in mantle cell lymphoma. Blood 2010, 115:2630-2639.

110. Fabbri M, Garzon R, Cimmino A, Liu Z, Zanesi N, Callegari E, Liu S, Alder H, Costinean S, Fernandez-Cymering C, Volinia S, Guler G, Morrison CD, Chan KK, Marcucci G, Calin GA, Huebner K, Croce CM: MicroRNA-29 family reverts aberrant methylation in lung cancer by targeting DNA methyltransferases 3A and 3B. Proc Natl Acad Sci U S A 2007 104:15805-15810.

111. Wang H, Garzon R, Sun H, Ladner KJ, Singh R, Dahlman J, Cheng A, Hall BM, Qualman SJ, Chandler DS, Croce CM, Guttridge DC: NF-kappaB-YY1-miR-29 regulatory circuitry in skeletal myogenesis and rhabdomyosarcoma. Cancer Cell 2008, 14:369-381.

112. Garzon R, Liu S, Fabbri M, Liu Z, Heaphy CE, Callegari E, Schwind S, Pang J, Yu J, Muthusamy N, Havelange V, Volinia S, Blum W, Rush LJ, Perrotti D, Andreeff M, Bloomfield CD, Byrd JC, Chan K, Wu LC, Croce CM, Marcucci G: MicroRNA-29b induces global DNA hypomethylation and tumor suppressor gene reexpression in acute myeloid leukemia by targeting directly DNMT3A and 3B and indirectly DNMT1. Blood 2009, 113:6411-6418

113. Boeri M, Verri C, Conte D, Roz L, Modena P, Facchinetti F, Calabro E, Croce CM, Pastorino U, Sozzi G: MicroRNA signatures in tissues and plasma predict development and prognosis of computed tomography detected lung cancer. Proc Natl Acad Sci U S A 2011, 108:3713-3718.

114. O'Day E, Lal A: MicroRNAs and their target gene networks in breast cancer. Breast Cancer Res 2010, 12:201.

115. Blenkiron C, Goldstein LD, Thorne NP, Spiteri I, Chin SF, Dunning MJ, Barbosa-Morais NL, Teschendorff AE, Green AR, Ellis IO, Tavaré S, Caldas C, Miska EA: MicroRNA expression profiling of human breast cancer identifies new markers of tumor subtype. Genome Biol 2007, 8:R214.

116. Xu J, Liao X, Wong C: Downregulations of B-cell lymphoma 2 and myeloid cell leukemia sequence 1 by microRNA 153 induce apoptosis in a glioblastoma cell line DBTRG-05MG. Int J Cancer 2010, 126:1029-1035.

117. Peltier HJ, Latham GJ: Normalization of microRNA expression levels in quantitative RT-PCR assays: identification of suitable reference RNA targets in normal and cancerous human solid tissues. RNA 2008, 14:844-852.

118. Ferrajoli A, Shanafelt TD, Ivan C, Shimizu M, Rabe KG, Nouraee N, Ikuo M, Ghosh AK, Lerner S, Rassenti LZ, Xiao L, Hu J, Reuben JM, Calin S, You MJ, Manning JT, Wierda WG, Estrov Z, O'Brien S, Kipps TJ, Keating MJ, Kay NE, Calin GA: Prognostic value of miR-155 in individuals with monoclonal B-cell lymphocytosis and patients with B chronic lymphocytic leukemia. Blood 2013, 122:1891-1899.
119. Iorio MV, Croce CM: MicroRNA dysregulation in cancer: diagnostics, monitoring and therapeutics. A comprehensive review. EMBO Mol Med 2012, 4:143-159.

120. Trang P, Wiggins JF, Daige CL, Cho C, Omotola M, Brown D, Weidhaas JB, Bader AG, Slack FJ: Systemic delivery of tumor suppressor microRNA mimics using a neutral lipid emulsion inhibits lung tumors in mice. $\mathrm{Mo}$ Ther 2011, 19:1116-1122

121. Gong C, Yao Y, Wang Y, Liu B, Wu W, Chen J, Su F, Yao H, Song E: Upregulation of miR-21 mediates resistance to trastuzumab therapy for breast cancer. J Biol Chem 2011, 286:19127-19137.

122. Nasser MW, Datta J, Nuovo G, Kutay H, Motiwala T, Majumder S, Wang B, Suster S, Jacob ST, Ghoshal K: Down-regulation of micro-RNA-1 (miR-1) in lung cancer. Suppression of tumorigenic property of lung cancer cells and their sensitization to doxorubicin-induced apoptosis by miR-1. J Biol Chem 2008, 283:33394-33405.

123. Nana-Sinkam SP, Croce CM: Clinical applications for microRNAs in cancer. Clin Pharmacol Ther 2013, 93:98-104.

124. Cheng CJ, Saltzman WM, Slack FJ: Canonical and non-canonical barriers facing antimiR cancer therapeutics. Curr Med Chem 2013, 20:3582-3593.

doi:10.1186/gm516

Cite this article as: Stahlhut and Slack: MicroRNAs and the cancer phenotype: profiling, signatures and clinical implications. Genome Medicine 2013 5:111. 